\title{
Existence and approximation of fixed points in convex metric spaces
}

\section{HAFIZ FUKHAR-UD-DIN}

\begin{abstract}
.
A fixed point theorem for a generalized nonexpansive mapping is established in a convex metric space introduced by Takahashi [A convexity in metric spaces and nonexpansive mappings, Kodai Math. Sem. Rep., 22 (1970), 142-149]. Our theorem generalizes simultaneously the fixed point theorem of Bose and Laskar [Fixed point theorems for certain class of mappings, Jour. Math. Phy. Sci., 19 (1985), 503-509] and the well-known fixed point theorem of Goebel and Kirk [A fixed point theorem for asymptotically nonexpansive mappings, Proc. Amer. Math. Soc., 35 (1972), 171-174] on a nonlinear domain. The fixed point obtained is approximated by averaging Krasnosel'skii iterations of the mapping. Our results substantially improve and extend several known results in uniformly convex Banach spaces and $C A T(0)$ spaces.
\end{abstract}

Acknowledgment. The author is grateful to King Fahd University of Petroleum \& Minerals for supporting research project IN121023.

\section{REFERENCES}

[1] Berinde, V., Iterative approximation of fixed points, Lectures Notes in Mathematics 1912, Springer-Berlin, 2007

[2] Berinde, V., On the convergence of Ishikawa iteration in the class of quasi contractive operators, Acta. Math. Univ. Comenianae, LXXIII (2004), No. 1, 119-126

[3] Blumenthal, L. M., Distance Geometry, Clarendon Press-Oxford, 1953

[4] Bose, S. C. and Laskar, S. K., Fixed point theorems for certain class of mappings, Jour. Math. Phy. Sci., 19 (1985), 503-509

[5] Browder, F. E., Nonexpansive nonlinear operators in Banach spaces, Proc. Nat. Acad. Sci. USA., 54 (1965), 1041-1044

[6] Busemann, H., Spaces with non-positive curvature, Acta Math., 80 (1948), 259-310

[7] Caristi, J., Fixed point theorems for mappings satisfying inwardness condition, Trans. Amer. Math. Soc., 215 (1976), 241-251

[8] Cegielski, A., Iterative methods for fixed point problems in Hilbert spaces, Lectures Notes in Mathematics, 2057, Springer-Verlag, 2012

[9] Chatterjea, S. K., Fixed point theorems, C. R. Acad. Bulgare Sci., 25 (1972), 727-730

[10] Chidume, C. E., Geometric properties of Banach spaces and nonlinear iterations, Lectures Notes in Mathematics, 1965, Springer-Verlag, 2009

[11] Fukhar-ud-din, H. and Khan, S. H., Convergence of iterates with errors of asymptotically quasi-nonexpansive mappings and applications, J. Math. Anal. Appl., 328 (2007), 821-829

[12] Fukhar-ud-din, H., Khan, A. R. and Akhtar, Z., Fixed point results for a generalized nonexpansive map in uniformly convex metric spaces, Nonlinear Anal., 75 (2012), 4747-4760

[13] Dhompongsa, S. and Panyanak, B., On $\triangle$-convergence theorems in CAT(0) spaces, Comp. Math. Appl., 56 (2008), 2572-2579

[14] Goebel, K. and Kirk, W., A fixed point theorem for asymptotically nonexpansive mappings, Proc. Amer. Math. Soc., 35 (1972), 171-174

[15] Goebel, K. and Reich, S., Uniform convexity, hyperbolic geometry and nonexpansive mappings, Monographs and Textbooks in Pure Appl. Math. vol. 83, Marcel Dekker Inc., 1984

Received: 12.05.2013; In revised form: 19.11.2013; Accepted: 15.01.2014

2010 Mathematics Subject Classification. 47H09, 47H10, 47J25.

Key words and phrases. Convex metric space, generalized nonexpansive mapping, fixed point, iterative procedure, strong convergence. 
[16] Goebel, K., Sekowski, T. and Stachura, A., Uniform convexity of the hyperbolic metric and fixed points of holomorphic mappings in the Hilbert ball, Nonlinear Anal., 4 (1980), 1011-1021

[17] Gohde, D., Zum Prinzip der Kontraktiven Abbildung, Math. Nachr., 30 (1965), 251-258

[18] Ibn Dehaish, B. A., Khamsi, M. A. and Khan, A. R., Mann iteration process for asymptotic pointwise nonexpansive mappings in metric spaces, J. Math. Anal. Appl., 397 (2013), 861-868

[19] Kannan, R., Some results on fixed points II, Amer. Math. Monthly, 76 (1969), 405-408

[20] Khamsi, M. A. and Khan, A. R., Inequalities in metric spaces with applications, Nonlinear Anal., 74 (2011), 4036-4045

[21] Khan, A. R., Khamsi, M. A. and Fukhar-ud-din, H., Strong convergence of a general iteration scheme in CAT(0) spaces, Nonlinear Anal., 74 (2011), 783-791

[22] Khan, A. R., Fukhar-ud-din, H. and Domlo, A. A., Approximating fixed points of some maps in uniformly convex metric spaces, Fixed Point Theory Appl., 2010 (2010) Article ID 385986, 11 pages

[23] Khan, A. R., Fukhar-ud-din, H. and Khan, M. A. A.,, An implicit algorithm for two finite families of nonexpansive maps in hyperbolic spaces, Fixed Point Theory and Appl., vol. 2012: 54 (2012), doi:10.1186/1687-1812-2012-54

[24] Kirk, W. A., Geodesic geometry and fixed point theory II, International Conference on Fixed Point Theory and Applications, Yokohama Publ., ( 2004), 113142

[25] Kirk, W. A. and Ray, W. O., A note on Lipschitzian mappings in convex metric spaces, Canad. Math. Bull., 20 (1977), 463-466

[26] Phuengrattana, W. and Suantai, S., Strong convergence theorems for a countable family of nonexpansive mappings in convex metric spaces, Abstract and Applied Analysis, Vol. 2011, Article ID 929037, 18 pages, doi:10.1155/2011/929037

[27] Prus, B. and Smarzewski, R. S., Strongly unique best approximation and centers in uniformly convex spaces, J. Math. Anal. Appl., 121 (1978), 85-92

[28] Reich, S., Some remarks concerning contraction mappings, Canad. Math. Bull, 14 (1971), 121-124

[29] Shimizu, T., A convergence theorem to common fixed points of families of nonexpansive mappings in convex metric spaces, Nonlinear Analysis and Convex Analysis, Yokohama Publishing, Japan (2007), 575-585

[30] Shimizu, T. and Takahashi, W., Fixed points of multivalued mappings in certain convex metric spaces, Topol. Methods Nonlinear Anal., 8 (1996), 197-203

[31] Takahashi, W., A convexity in metric spaces and nonexpansive mappings, Kodai Math. Sem. Rep., 22 (1970), 142-149

[32] Talman, L. A., Fixed points for condensing multifunctions in metric spaces with convex structure, Kodai Math. Sem. Rep., 29 (1977), 62-70

[33] Veeramani, P., On some fixed point theorems on uniformly convex Banach spaces, J. Math. Anal. Appl., 167 (1992), 160-166

[34] Zhou, H. Y., Guo, G. T., Hwang, H. J. and Cho, Y. J., On the iterative methods for nonlinear operator equations in Banach spaces, PanAmer. Math. Journal, 14 (2004), 61-68

\title{
Department of MATHEMATics And STATistics \\ King FAHD University of PETROLEUM AND Minerals \\ DHAHRAN 31261, SAUDi ARABiA
}

\author{
DEPARTMENT OF MATHEMATICS \\ THE ISLAMIA UNIVERSITY OF BAHAWALPUR \\ BAHAWALPUR 63100, PAKISTAN \\ E-mail address: hfdin@kfupm.edu.sa; hfdin@yahoo.com
}

